\title{
2F $F_{S} A_{P} C_{A} H_{C}$
}

FSC-ESD-217-90-478B

\section{CRAF/Cassini Contingency Plans}

Using Only Existing Pu ${ }^{238}$ Inventory

\author{
Marshall Eck
}

October 25, 1990 


\section{DISCLAIMER}

This report was prepared as an account of work sponsored by an agency of the United States Government. Neither the United States Government nor any agency Thereof, nor any of their employees, makes any warranty, express or implied, or assumes any legal liability or responsibility for the accuracy, completeness, or usefulness of any information, apparatus, product, or process disclosed, or represents that its use would not infringe privately owned rights. Reference herein to any specific commercial product, process, or service by trade name, trademark, manufacturer, or otherwise does not necessarily constitute or imply its endorsement, recommendation, or favoring by the United States Government or any agency thereof. The views and opinions of authors expressed herein do not necessarily state or reflect those of the United States Government or any agency thereof. 


\section{DISCLAIMER}

Portions of this document may be illegible in electronic image products. Images are produced from the best available original document. 
FSC-ESD-217-90-478B

\section{CRAF/Cassini Contingency Plans \\ Using Only Existing Pu ${ }^{238}$ Inventory}

Marshall Eck

October 25, 1990 


\section{Acknowledgement}

The material presented in this report drew heavily from Fairchild Space report FSC-ESD. 217-90-469A. Without the thorough design analysis and parametric evaluations conducted by A. Schock, T. Or and H. Noravian, the current effort could not have been performed.

The author thanks Brian Valenti for his assistance in the preparation of the contingency program-plans. Finally, the author greatfully acknowledges the efforts of $R$. Crites and $K$. Yates for their assistance in the preparation and compilation of this manuscript. 


\section{INTRODUCTION AND SUMMARY}

The availability of $\mathrm{Pu}^{238}$ fuel for the CRAF/Cassini (C/C) program is discussed in this report. The current SRS fuel irradiation plan (based on using SRS Reactor 2) calls for powder shipment on $30 \mathrm{Mar} 93$. Because of this late new fuel availability date, a blending plan was developed which allows the fabrication of four GPHS heat sources ( 72 modules) using only existing fuel. Under this plan fueled clads for these modules will be encapsulated at an average $\mathrm{Pu}^{238}$ enrichment of 82.8 percent. When decayed from the encapsulation dates to the launch dates shown in the current $\mathrm{C} / \mathrm{C}$ program plan, the $\mathrm{BOM}$ module power becomes approximately 240 watt $(t)$ for either mission.

Two $\mathrm{C} / \mathrm{C}$ contingency plans are proposed. In the first (the F-8 contingency plan) three RTGs (F-2, F-5 and F-6) are used on a Cassini VEJGA trajectory launch on 28 Nov 95. This approach provides a power margin of +175 watt (e) eight years after launch and +130 watt (e) 10.8 years after launch. The Cassini launch is followed in Jan 96 by the CRAF mission using RTGs F-7 and F-8. The CRAF configuration provides a +19 watt (e) power margin five years after launch and a - 4 watt (e) margin 7.5 years after launch. All of the mission margins are based on the maximum possible power predicted for various RTGs when using 240 watt $(t)$ BOM modules. These margins include no provision for specialized cover gas management.

Under the F-8 contingency plan, the E-9 converter would be assembled as a spare. If, as some fear, F-5 does not survive the preload adjustment maneuver, F-2 could be loaded with the existing F-5 heat source without fuel reprocessing and without an adverse schedule impact. This would require fueling E-9, and would leave the CRAF program without a spare.

Although the programmatic risks of the proposed plan may be increased over those perceived for the current plan, it must be remembered that the assumption that new fuel will be available in a timely fashion is not itself without risk. Further, even if new fuel is forthcoming and complex gas management maneuvers are performed, Cassini still will not meet the mission power goals. Potential gas management maneuvers are as yet undefined and may, therefore, impact both program risk and mass margin. 
A second contingency plan (the F-9 contingency plan) involving flying three RTGs on both missions was also investigated. This plan does not allow a second mission launch until Sept. 96.

On balance, it was concluded that a program plan which includes the fabrication of four GPHS heat sources and four GPHS thermoelectric converters and assigns three RTGs (F-2, F5 and F-6) to a 28 Nov 95 Cassini VEJGA launch and two RTGs (F-7 and F-8) to a CRAF launch on or after $28 \mathrm{Jan} 96$ is more likely to produce satisfactory science than are the current or the F-9 contingency program-plans. Top level schedules and preliminary budget information sorted by funding agency and spread by fiscal year are presented in support of both the proposed contingency program-plans.

It is recognized that having three RTGs on one Mariner Mark II and two RTGs on another will present spacecraft qualification problems. It should be possible to qualify both configurations with small incremental costs if mass mock-ups are used for RTGs in all of their various intended locations. By qualifying the three RTG Cassini configuration first, it should be relatively easy to remove the third generator mass mock-up and requalify Mariner in a two RTG configuration.

Although the three-RTG approach for Cassini incurs qualification problems with the spacecraft, it enables the science. This approach is not only possible but may be preferable to the current plan. It is recommended that this suggested change to the $\mathrm{C} / \mathrm{C}$ program plan be discussed with JPL management by DOE management. 


\section{TECHNICAL DISCUSSION}

Initial calculations to address CRAF/Cassini mission power requirements were performed for DOE by A. Schock and transmitted, by DOE direction, to JPL 01 Oct 90 . These calculations showed that a serious power shortfall occurs in both missions if no new fuel is available. Examination of key dates which were extracted from the DOE C/C RTG Program Management System data base showed that new fuel must be shipped from SRS HB Line no later than 25 Nov 91 if existing schedule contingency is to be maintained. Powder shipment after 25 Apr 92 would slip the current CRAF launch schedule.

The material presented in this chapter was initially developed to explore the impact which lack of new fuel would have on power availability for the $\mathrm{C} / \mathrm{C}$ missions. During the course of this effort, a strategy became apparent which would allow both missions to fly on schedule with adequate power availability. This strategy involves launching three RTGs (F-2, F-5, and F-6) on Cassini on 28 Nov 95 and two RTGs on CRAF 28 Jan 96.

The remainder of the material in this chapter is organized into the following sections:
A. Problem Statement
B. Fuel Availability and Enrichment
C. Cassini Power Availability
D. CRAF Power Availability
E. Contingency Program-Plans

\section{A. Problem Statement}

The object of the $\mathrm{C} / \mathrm{C}$ mission is to obtain scientific information. Under the existing program-plan, the RTG power supplies for this mission provide substantially less power than is necessary to perform the desired science. It is assumed that a management reserve is being held in the "engineering" portion of the power budget; however, the extent of this reserve is unknown. Given that we appear to be entering management reserve at program initiation, it was reasoned that ways of obtaining more power from the GPHS-RTG should be explored. 
Detailed examination of the current C/C Program Management System data base showed that there was very little time available to obtain new fuel either from the SRS Reactors or from the Soviets. A summary of the key activities in the current $\mathrm{C} / \mathrm{C}$ program plan is presented in Table 1. Since there is a management reserve in the current program plan, these dates could slip somewhat without impacting the launches; however, the restart date for SRS Reactors 2 and 3 is not well known at this time. The key activities shown in Table 1 interact with a number of other program activities. The general flow of these activities is shown in the summary schedule charts presented as Figure 1.

Table 1: Key Activities in Current CRAF/Cassini Program Plan

\begin{tabular}{|c|c|c|c|c|c|}
\hline \multirow{3}{*}{ Unit } & \multicolumn{5}{|c|}{ Activity } \\
\hline & \multirow{2}{*}{$\begin{array}{l}\text { Ship Feed } \\
\text { Powder } \\
\text { Late Finish }\end{array}$} & \multicolumn{2}{|c|}{ Pellet Encapsulation } & \multirow[t]{2}{*}{ Launch CRAF } & \multirow[t]{2}{*}{ Launch Cassini } \\
\hline & & Late Start & Late Finish & & \\
\hline F-5 & - & - & - & 22 Aug 95 & - \\
\hline F-2 & 25 Nov 91 & 18 Sep 92 & 03 Mar 93 & 22 Aug 95 & - \\
\hline F-6 & 28 May 92 & 06 Apr 93 & $14 \mathrm{Sep} 93$ & - & 08 Apr 96 \\
\hline F-7 & 19 Nov 92 & 15 Oct 93 & 05 Apr 94 & - & 08 Apr 96 \\
\hline F-8 & 16 Jun 93 & 10 May 94 & 13 Oct 94 & - & Spare \\
\hline
\end{tabular}

The interaction of the CRAF mission power demand and the available power is shown in Figure 2 for three assumed GPHS module initial fuel loadings. Table 2 shows the enrichment, state and location of all currently available $\mathrm{Pu}^{238}$ decayed to $01 \mathrm{Sep} 90$. The average enrichment as of $01 \mathrm{Sep} 90$ is seen to be approximately 82 percent and to vary over a range of 77.6 to 83.6 percent. Examination of Figure 2 shows that if we loaded today, we could obtain between 240 and 245 watt ( $t$ ) per GPHS module using fuel from the existing fuel inventory. If we enter Figure 2 on the 240 watt ( $t) /$ module line, we see that there is a 


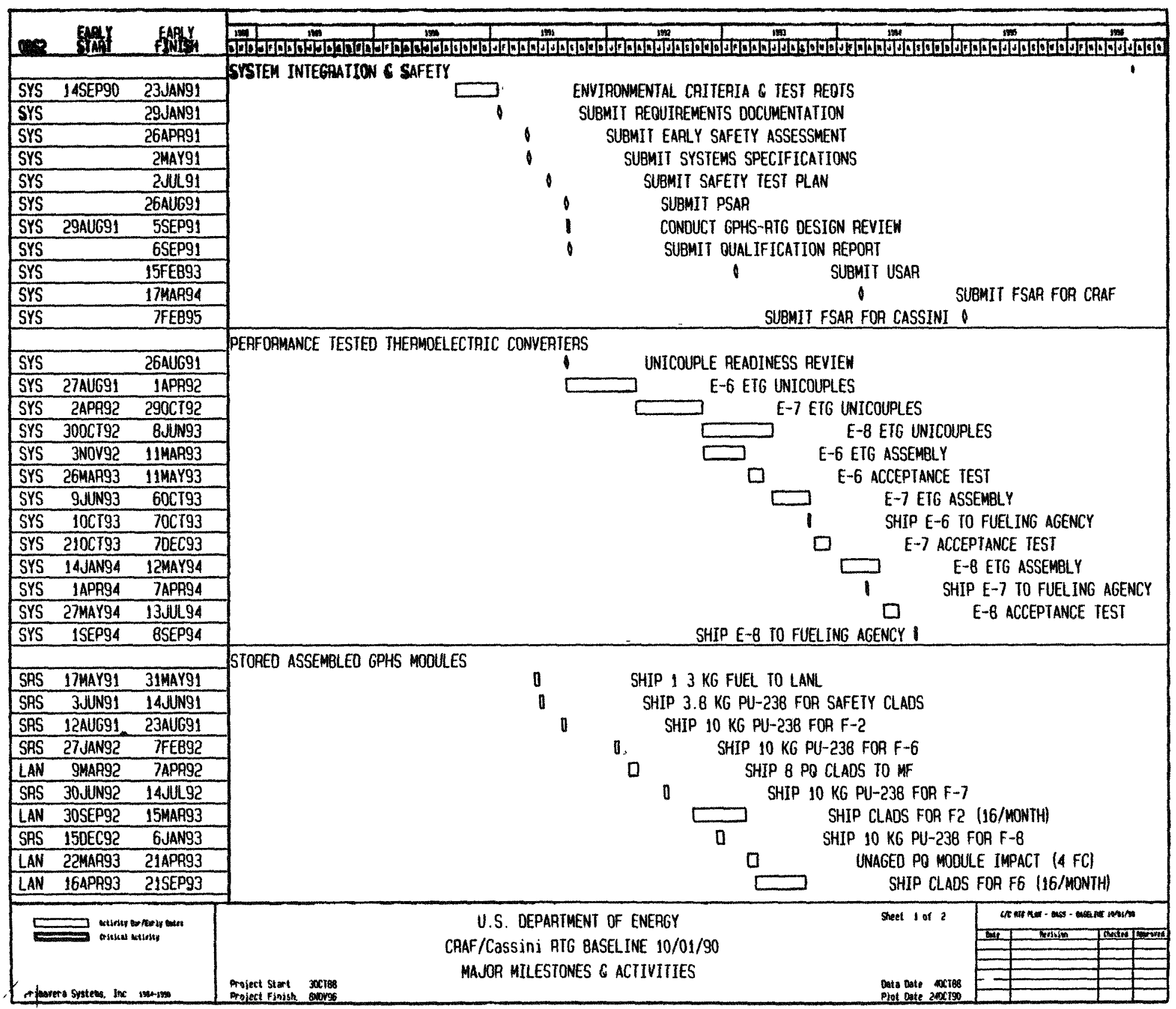

Figure 1 (Page 1 of 2) 


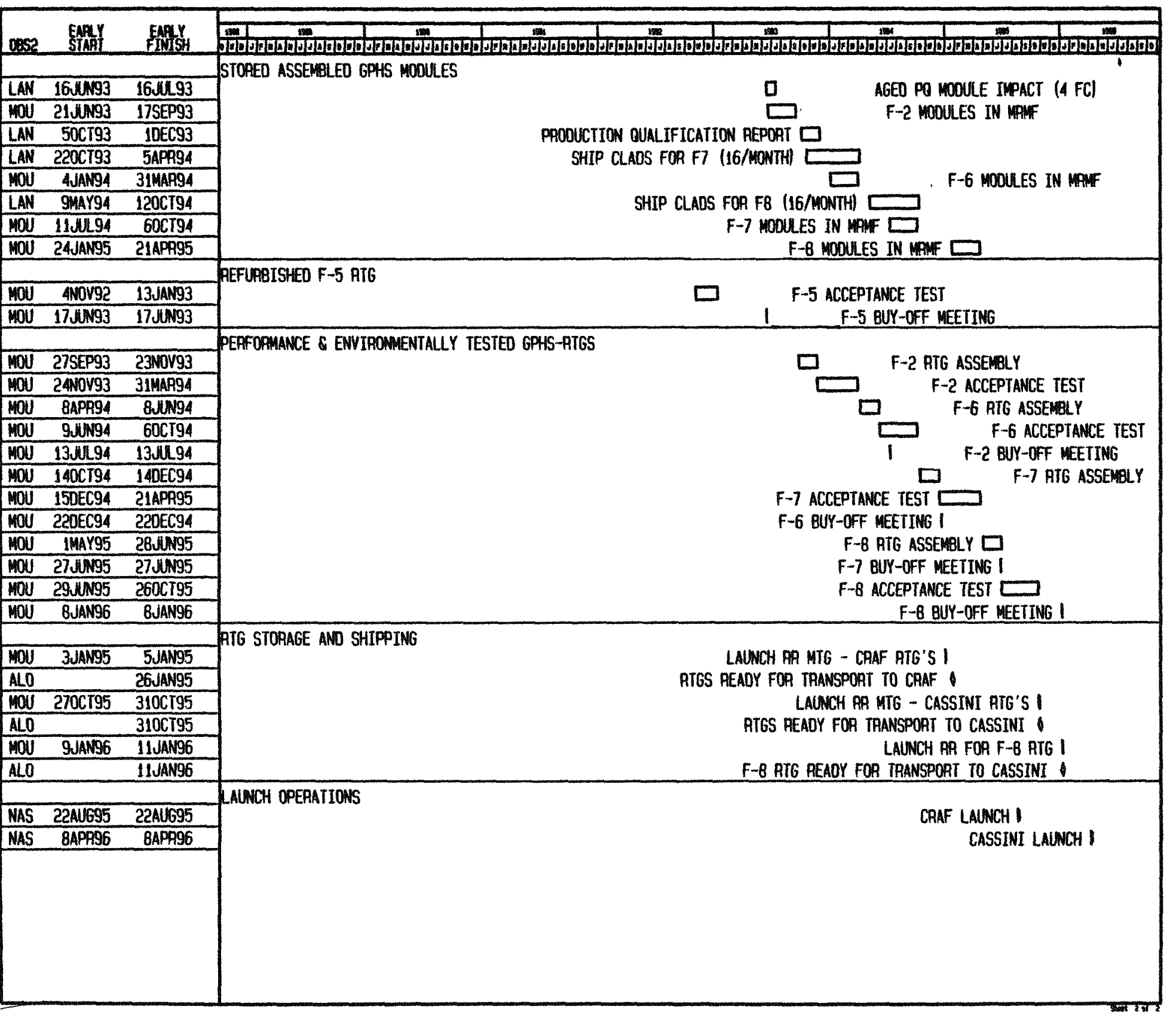

Figure 1 (Page 2 of 2) 
Figure 2 CRAF Mission Power Supply and Demand as a Function of Time

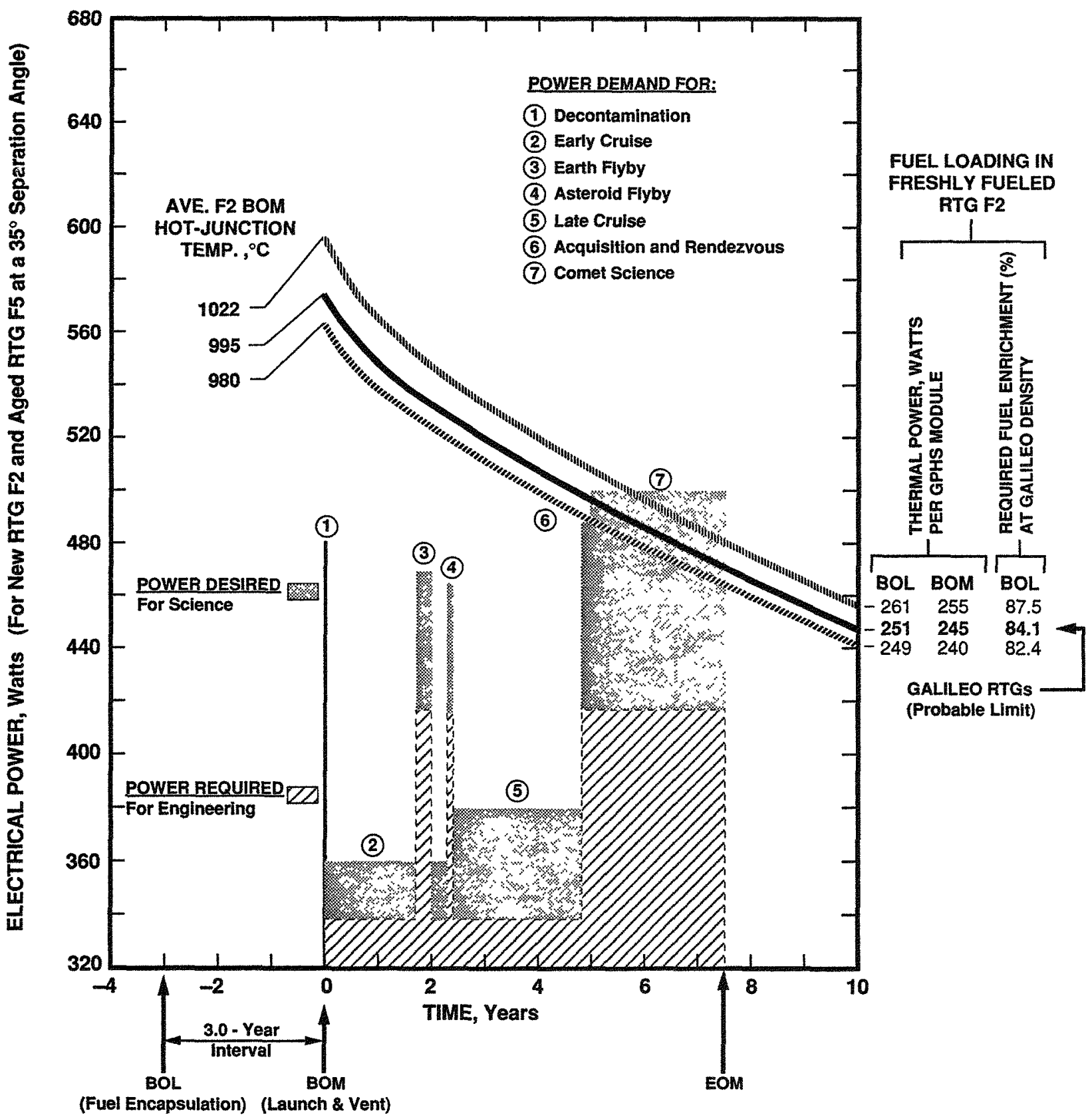


Table 2. Current $\mathrm{Pu}^{238}$ Inventory $(1)$

(Decayed to $9 / 1 / 90)$

\begin{tabular}{|c|c|c|c|c|}
\hline Site & Identification & $\begin{array}{l}\mathrm{Pu}^{238} \\
(\mathrm{~kg})\end{array}$ & $\begin{array}{l}\text { Total Pu } \\
(\mathrm{kg})\end{array}$ & $\begin{array}{l}\text { Isotopic } \\
\text { Concentration } \\
\%, \mathrm{Pu}^{238}\end{array}$ \\
\hline SRS & $\begin{array}{l}\text { Product } \\
\text { PEF } \\
\text { Scrap Product } \\
\text { Suspect Mat'l } \\
\text { MHW } \\
\text { Scrap }(>80 \%) \\
\text { Scrap }(<80 \%)\end{array}$ & $\begin{array}{l}9.46 \\
6.55 \\
2.77 \\
2.20 \\
2.53 \\
7.70 \\
8.47\end{array}$ & $\begin{array}{c}11.37 \\
7.88 \\
3.31 \\
2.65 \\
3.17 \\
9.25 \\
10.92\end{array}$ & $\begin{array}{l}83.24 \\
83.10 \\
83.63 \\
83.19 \\
80.09 \\
83.21 \\
77.56\end{array}$ \\
\hline LANL & $\begin{array}{l}\text { Development } \\
\text { Scrap }\end{array}$ & $\begin{array}{l}3.66 \\
1.68\end{array}$ & $\begin{array}{l}4.42 \\
2.13\end{array}$ & $\begin{array}{l}82.84 \\
78.81\end{array}$ \\
\hline Mound & $\begin{array}{l}\text { Q-1 } \\
\text { GPHS-Mods } \\
\text { Fueled Clads } \\
\text { MHW }\end{array}$ & $\begin{array}{l}7.33 \\
0.74 \\
1.96 \\
6.58\end{array}$ & $\begin{array}{l}8.90 \\
0.90 \\
2.38 \\
7.93\end{array}$ & $\begin{array}{l}82.36 \\
82.39 \\
82.43 \\
82.96\end{array}$ \\
\hline \multicolumn{2}{|c|}{$\begin{array}{l}\text { TOTAL } \\
\text { TOTAL (7/96) }\end{array}$} & $\begin{array}{l}61.64 \\
59.46\end{array}$ & $\begin{array}{l}75.21 \\
73.13^{(2)}\end{array}$ & $\begin{array}{l}81.96 \\
81.3\end{array}$ \\
\hline
\end{tabular}

(1) Extracted from a memo from A.P. Gouge to J.E. Dickenson 30 Aug 90.

(2) Note that subtraction of the total $\mathrm{Pu}$ and $\mathrm{Pu}^{238}$ values at July 96 from the values given at 01 Sep 90 give different results. This difference seems high for $\mathrm{Pu}^{2 \mathrm{X}}$ decay in six years. 
significant science-power shortfall by the end of the CRAF mission (EOM). The details of this power shortfall are shown in Table 3 for three assumed GPHS-module fuel loadings.

The interaction of the Cassini mission power demand and the available power is shown in Figure 3 for three assumed GPHS module initial fuel loadings. If as in the case of CRAF, we enter Figure 3 at a BOL enrichment of 82 percent, we see that, at EOM, the power available for Saturn science is less than half of the desired science power. The details of this power shortfall are shown in Table 4 for three assumed GPHS-module fuel loadings.

The magnitude of the power shortfall predicted for Cassini science prompted a suggestion, at the 19 June 90 meeting at JPL, that RTG power output could be improved if the thermoelectric (T/E) material degradation which normally occurs during transit to Saturn could be eliminated. It was pointed out that if the resulting reduction in coast power were acceptable, cover gas venting of the RTGs could be delayed until Satum injection. The lower temperature which the T/E material would see when there is an internal gas present results in both reduced power output and reduced T/E material degradation.

A study was undertaken to determine the effects of various delayed venting strategies. A summary of the results of this study is presented in Table 5. If there is no new fuel and we are limited to 240 watt ( $(t)$ per GPHS module and two RTGs, a significant Saturn-science power shortfall still remains. As was noted previously, the power increase obtained from delayed venting is purchased with a power decrease during coast. Examination of Figure 4 shows that there is a considerable shortfall of coast power from venting schemes which allow significant helium buildup. Since helium is a natural product of $\mathrm{Pu}^{238} \alpha$-decay, it is clear that a complex gas management scheme would be needed to meet the stated coast power requirements. Coast power requirements could be reduced by instrument cycling; however, JPL personnel have indicated that cycling of their instruments may have unacceptable reliability consequences.

A number of other potential approaches to increasing GPHS-RTG power have been studied. Each has advantages and disadvantages, but none can produce the desired power using a heat source assembled from GPHS modules which produce 240 watt $(t)$ at launch 
Table 3. Predicted Performance of two CRAF RTGs (F-2 and F-5) as a Function of Initial Thermal Loading of F-2 (1)

\begin{tabular}{|c|c|c|c|c|c|c|c|}
\hline $\begin{array}{l}\text { F-2 Module } \\
\text { Power BOM } \\
\text { Watts (t) }\end{array}$ & $\begin{array}{l}\mathrm{F}-2^{(2)} \mathrm{Pu}^{238} \\
\text { Enrichment } \\
\text { (BOL) } \\
\%\end{array}$ & $\begin{array}{l}\text { Average T/E } \\
\text { Hot Junction } \\
\text { Temp } \\
\text { (BOM) }^{(3)} \\
{ }^{\circ} \mathrm{C}\end{array}$ & $\begin{array}{l}\text { Approximate } \\
\text { Coast Power } \\
\text { Launch to } \\
5 \text { years } \\
\text { Watts (e) }\end{array}$ & $\begin{array}{l}\text { RTG Power } \\
\text { After } \\
5 \text { years } \\
\text { Watts (e) }\end{array}$ & $\begin{array}{l}\text { RTG Power } \\
\text { Margin After } \\
5 \text { years }(4) \\
\text { Watts (e) }\end{array}$ & $\begin{array}{l}\text { RTG Power } \\
\text { After } \\
7.5 \text { years } \\
\text { (EOM) } \\
\text { Watts (e) }\end{array}$ & $\begin{array}{l}\text { RTG Power } \\
\text { Margin After } \\
7.5 \text { years }(4) \\
\text { (EOM) } \\
\text { Watts (e) }\end{array}$ \\
\hline 255 & 87.5 & 1022 & $595-517$ & 517 & +18 & 494 & -5 \\
\hline 245 & 84.1 & 995 & 574-505 & 505 & +6 & 482 & -17 \\
\hline 240 & 82.4 & 980 & $563-497$ & 497 & -2 & 475 & -24 \\
\hline
\end{tabular}

(1) F-5 is an existing aged generator with an approximate BOM thermal loading of 227 watts on 28 Aug 1995.

(2) At encapsulation (BOL).

(3) Assuming three years elapsed time between encapsulation (BOL) and launch (BOM).

(3) Based on a JPL desired power of 499 watts (e) to perform Comet science. 
Figure 3 Cassini Mission Power Supply and Demand as a Function of Time

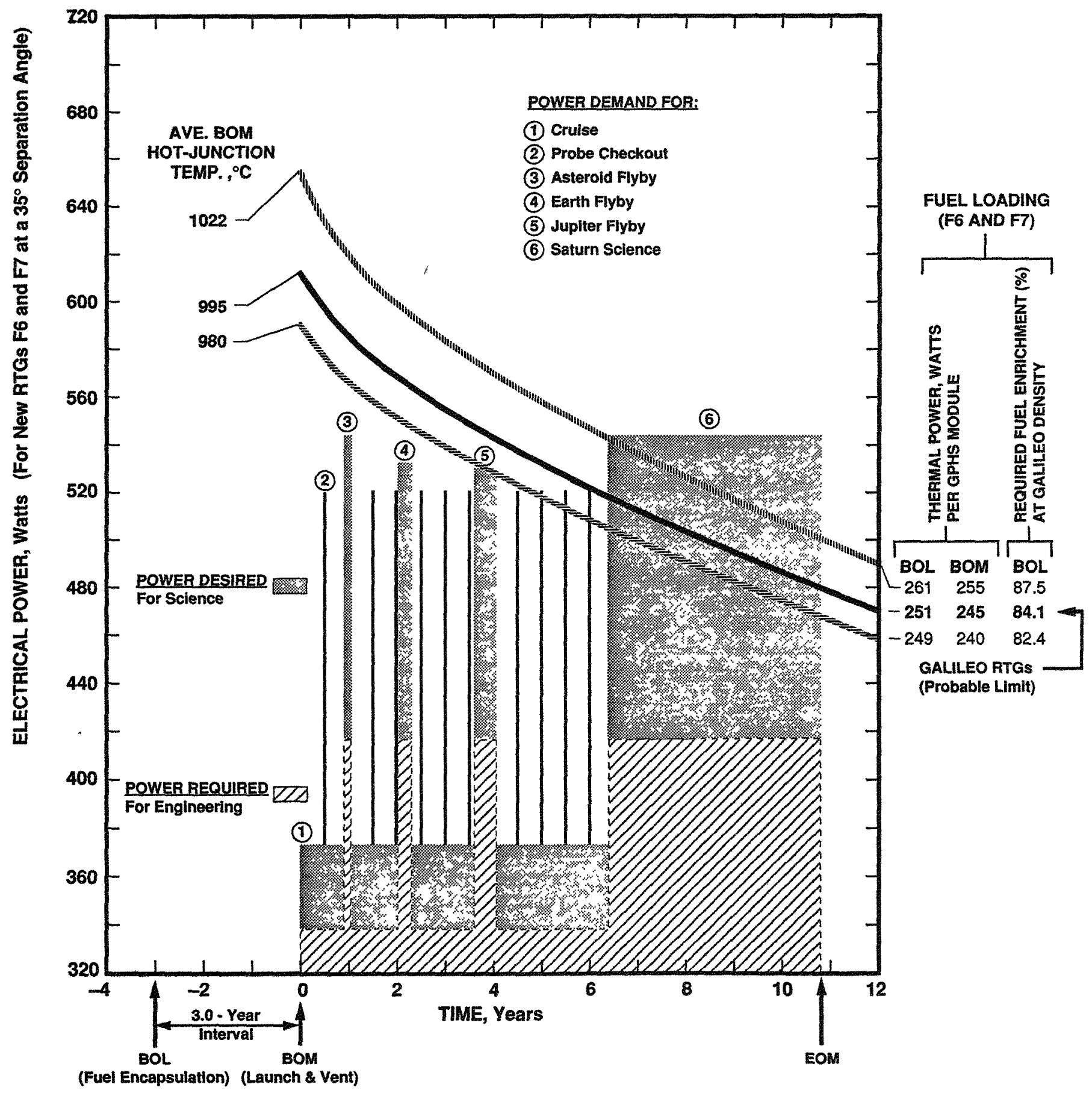


Table 4. Predicted Performance of two Cassini RTGs (F-7 and F-8) as a Function of Initial Thermal Loading

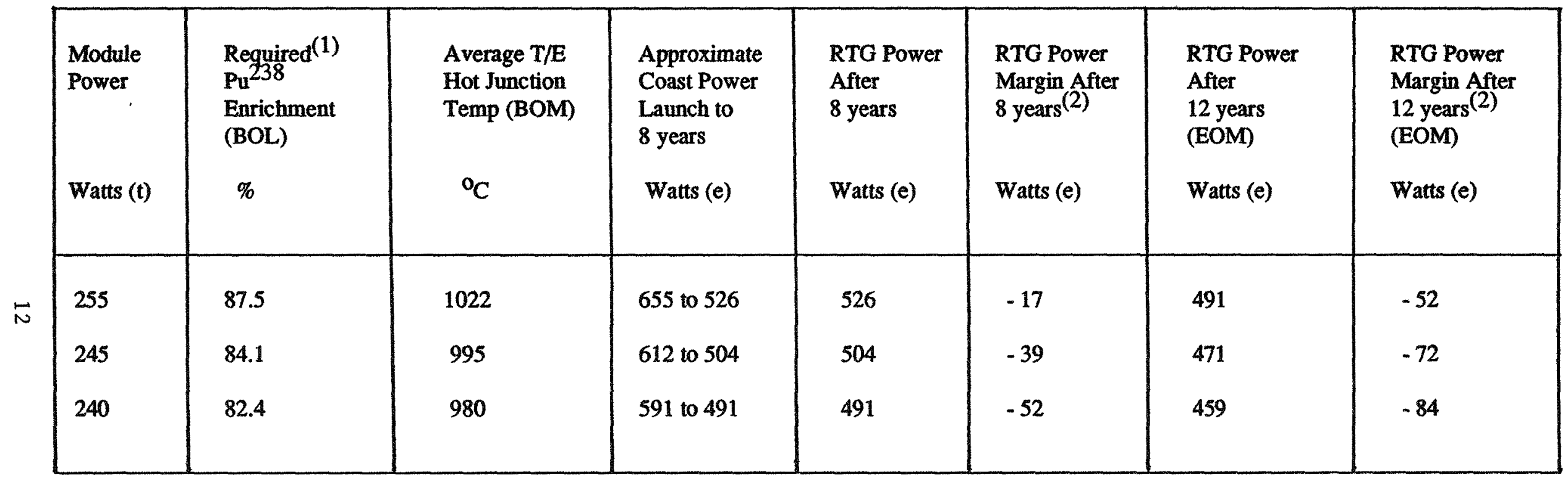

(1) At encapsulation (BOL). Assuming three years elapsed time between encapsulation (BOL) and launch (BOM).

(2) Based on a JPL desired power of 543 watts (e) to perform Saturn science. 
Table 5. Predicted Performance of two Cassini RTGs (F-7 and F-8) as a Function of Venting Strategy and Initial Thermal Loading

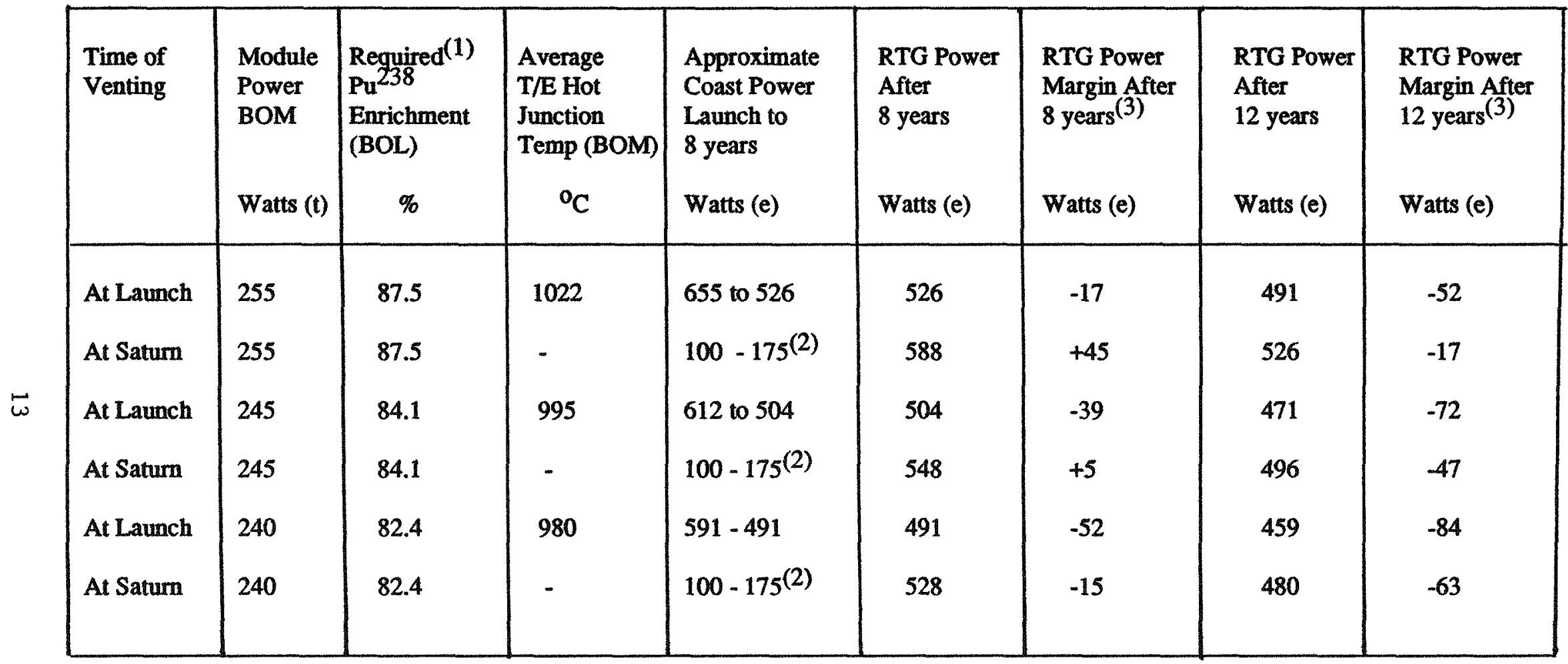

(1) At encapsulation (BOL). Assuming three years elapsed time between encapsulation (BOL) and launch (BOM).

(2) Assuming a helium continuum. Exact effect of helium is unknown pending results of tests on Q-1 and F-5.

(3) Based on a JPL desired power of 543 watts (e) to perform Saturn science.

NOTE: The predicted powers shown in this table contain no margin. As such, they represent the maximum attainable powers for generators mounted with a $35^{\circ}$ angle between their axes per the current Cassini baseline. 
Figure 4 Effect of Various Cover Gas Venting Strategies on Cassini RTG Power Output BOM Fuel Loading $=245$ Watts/Module

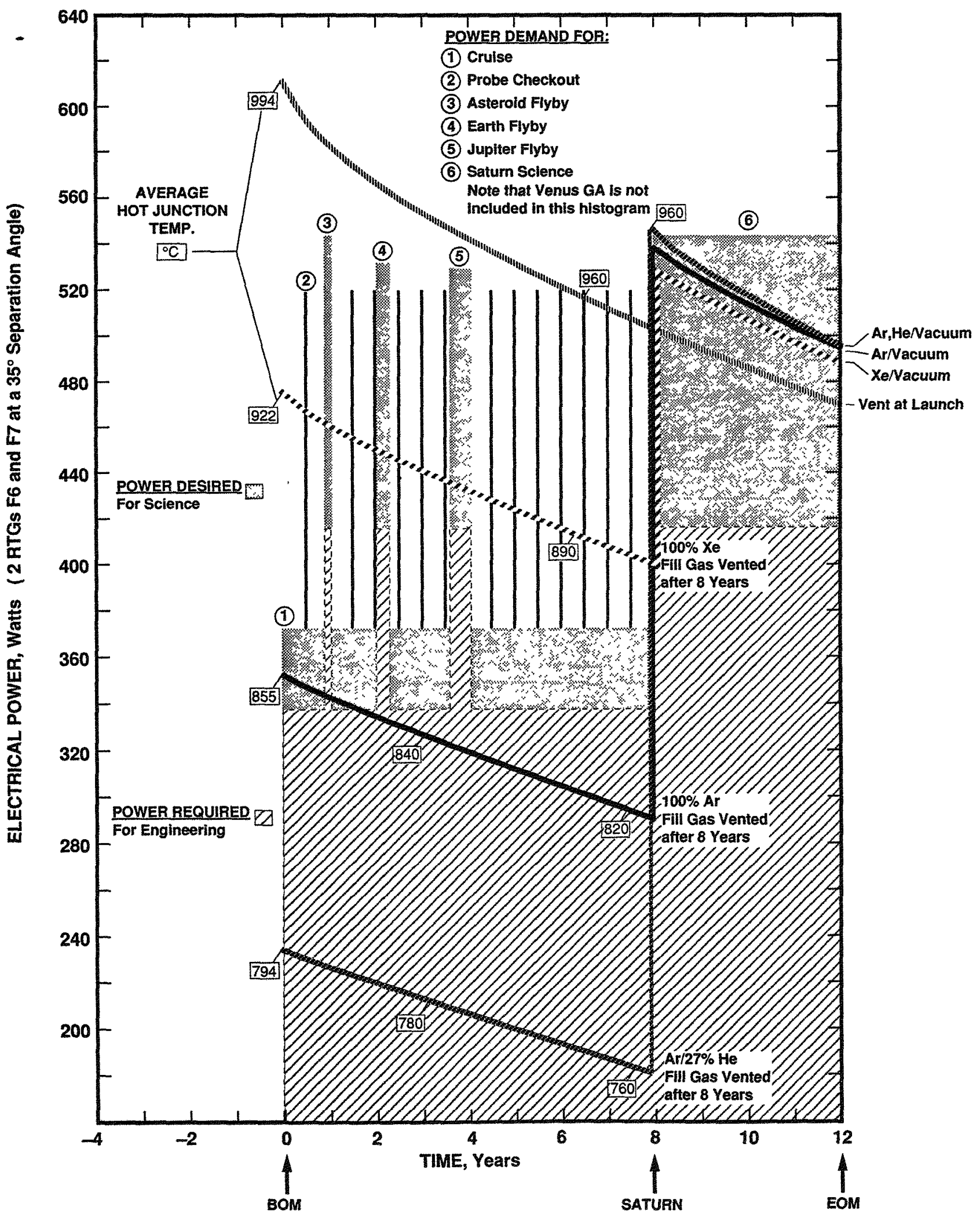


(BOM). Nibbling at the margin will not get us Saturn-science power. There is clearly a need for a more global solution than has been proposed to date. It is at this point that we introduce such a global solution.

- We know from other contingency planning that a Cassini VEJGA trajectory launch opportunity exists 28 Nov 95 . We also know that this trajectory provides adequate mass margin to carry a third RTG. In addition, a CRAF launch opportunity exists 28 Jan 96. Therefore, if we invert the currently planned order of launch we can delay the first launch requirement by three months and fly F-2, F-5, and F-6 on Cassini as well as having E-7 available for fueling as a Cassini spare. Since we had planned to have the E-8 generator ready to use as a spare for the Cassini launch originally scheduled for 08 April 96, the CRAF could be flown at the 28 Jan 96 launch opportunity using F-7 and F-8. If E-7 is needed as a spare for Cassini, E-9 must be assembled, fueled, and tested. In this eventuality, there would be no spare for CRAF. The foregoing scenario will be used as a basis for the development of two contingency plans. These plans will be discussed in detail in subsequent sections.

\section{B. Fuel Availability and Enrichment}

A first order blending study was performed to determine if sufficient fuel of a sufficiently high $\mathrm{Pu}^{238}$ enrichment exists to satisfy the proposed contingency-plan requirements for the fabrication of four complete heat sources. This first order study was based on the $\mathrm{Pu}^{238}$ inventory description presented in Table 2.

It previously has been shown (FSC-ESD-217-90-477) that the average fueled clad fabricated for the Galileo/Ulysses programs contained $150 \mathrm{gm}$ of fuel. If we assume that chemical separation is 90 percent efficient and that pelletization thru encapsulation is also 90 percent efficient we see that four GPHS heat sources ( 72 modules) will require $47 \mathrm{~kg}$ of $\mathrm{Pu}$. By selecting the higher enrichment sources from Table 2, we quickly see that $53 \mathrm{~kg}$ of $\mathrm{Pu}$ containing 83 percent $\mathrm{Pu}^{238}$ are available as of 01 Sep 90 . If we assume that chemical separation can be accomplished at approximately the time that feed powder is required for F-2 (see Table 1) we will still have -82.9 percent enrichment at encapsulation (BOL). Similarly, F-7 powder separated at the time required to meet the 19 Nov 92 shipping date will be 82.8 
percent enriched. For the purpose of this exercise, the fuel delivery dates shown in the current C/C Program Management System data base will be essentially unchanged in the contingency program-plans. The remainder of the material in this section is based on a new Program Management System data base generated specifically for the proposed contingency-plans.

\section{1. $\quad \mathrm{Pu}^{238}$ Mass and Enrichment Calculations at Encapsulation (BOL)}

The values shown in Table 6 for $\mathrm{Pu}^{238}$ mass and enrichment after 01 Sep 90 were calculated by assuming that the mass of all $\mathrm{Pu}$ isotopes other than $\mathrm{Pu}^{238}$ remained constant over the time period of interest. The mass of all other isotopes of plutonium $\left(\mathrm{Pu}^{2 \mathrm{XX}}\right)$ was then determined by subtracting the $\mathrm{Pu}^{238}$ mass from total $\mathrm{Pu}$ mass shown in Table 2 (after Gouge). $\mathrm{Pu}^{238}$ mass was calculated at two subsequent times using the relation shown in Equation 1. This relation is approximately correct since 99.9 percent of the available heat comes from the decay of $\mathrm{Pu}^{238}$.

$$
M_{t}=M_{0} e^{-\lambda t}
$$

where:

$$
\begin{aligned}
M_{t} & =\mathrm{Pu}^{238} \text { mass at time of interest, } \mathrm{gm} \\
\mathbf{M}_{\mathrm{o}} & =\text { Initial } \mathrm{Pu}^{238} \text { mass, gm } \\
\mathrm{e} & =2.7183 \\
\lambda & =\ln 2 / \text { isotopic half life, years } \\
\mathbf{t} & =\text { time of interest, years }
\end{aligned}
$$

Total Pu mass may be determined for any time of interest after 01 Sep 90 by adding $M_{t}$ and the value of $\mathrm{Pu}^{2 \mathrm{XX}}$ given in Table 6. $\mathrm{Pu}^{238}$ enrichment may then be determined by dividing the $\mathrm{Pu}^{238}\left(\mathrm{M}_{\mathrm{t}}\right)$ mass by the total Pu mass.

\section{GPHS Thermal Power at Launch (BOM)}

Reference to the C/C Program Management System data base shows that, on average, it will be 3.75 years between fuel-pellet feed-powder chemical separation and the launch of the 
Table 6. Estimate of Thermal Power Availability as a Function of Several Assumed Decay Pathways ${ }^{(1)}$

\begin{tabular}{|c|c|c|c|c|c|c|c|c|c|c|c|}
\hline \multirow[t]{2}{*}{$\begin{array}{l}\text { Current } \\
\text { Locations }\end{array}$} & \multirow[t]{2}{*}{ Source } & \multicolumn{4}{|c|}{$\begin{array}{l}\mathrm{Pu}^{238} \text { Inventory } \\
\text { Decayed to } 01 \text { Sep } 90^{(2)}\end{array}$} & \multicolumn{3}{|c|}{$\begin{array}{l}\mathrm{Pu}^{238} \text { Inventory } \\
\text { Decayed to Time of Cassini } \\
\text { (F-2) Powder Chemical } \\
\text { Separation } 25 \text { Nov } 91\end{array}$} & \multicolumn{3}{|c|}{$\begin{array}{l}\mathrm{Pu}^{238} \text { Inventory } \\
\text { Decayed to Time of F-7 } \\
\text { (Ave. CRAF) Powder Chemical } \\
\text { Separation } 19 \text { Nov } 92\end{array}$} \\
\hline & & $\begin{array}{l}\text { Total Pu } \\
\text { kg }\end{array}$ & $\begin{array}{l}\mathrm{Pu}^{238} \\
\mathrm{~kg}\end{array}$ & $\begin{array}{l}\text { Isotopic } \\
\text { Enrichment } \\
\% \mathbf{P u}^{238}\end{array}$ & $\begin{array}{c}\text { Total(3) } \\
\mathrm{Pu}^{2 \mathrm{XX}} \\
\mathrm{kg}\end{array}$ & $\begin{array}{l}\text { Total Pu } \\
\mathrm{kg}\end{array}$ & $\begin{array}{l}\mathrm{Pu}^{238} \\
\mathrm{~kg}\end{array}$ & $\begin{array}{l}\text { Isotopic } \\
\text { Enrichment } \\
\% \mathbf{P u}^{238}\end{array}$ & $\begin{array}{c}\text { Total Pu } \\
\text { kg }\end{array}$ & $\begin{array}{l}\mathrm{Pu}^{238} \\
\mathrm{~kg}\end{array}$ & $\begin{array}{l}\text { Isotopic } \\
\text { Enrichment } \\
\text { \% Pu }\end{array}$ \\
\hline SRS & $\begin{array}{l}\text { Product } \\
\text { PEF } \\
\text { Scrap Product } \\
\text { Suspect Mat'1 } \\
\text { MHW } \\
\text { Scrap }(>80 \%) \\
\text { Scrap }(<80 \%)\end{array}$ & \begin{tabular}{c|}
11.37 \\
7.88 \\
3.31 \\
2.65 \\
3.17 \\
9.25 \\
10.92
\end{tabular} & $\begin{array}{l}9.46 \\
6.55 \\
2.77 \\
2.20 \\
2.53 \\
7.70 \\
8.47\end{array}$ & \begin{tabular}{|l|}
83.24 \\
83.10 \\
83.63 \\
83.19 \\
80.09 \\
83.21 \\
77.56
\end{tabular} & $\begin{array}{c}1.91 \\
1.33 \\
0.54 \\
- \\
- \\
1.55 \\
-\end{array}$ & $\begin{array}{l}11.28 \\
7.82 \\
3.28 \\
- \\
- \\
9.17 \\
-\end{array}$ & $\begin{array}{c}9.37 \\
6.49 \\
2.74 \\
- \\
- \\
7.62 \\
-\end{array}$ & $\begin{array}{c}83.1 \\
83.0 \\
83.5 \\
- \\
- \\
83.1 \\
-\end{array}$ & $\begin{array}{l}11.20 \\
7.76 \\
3.26 \\
- \\
- \\
9.11\end{array}$ & $\begin{array}{c}9.29 \\
6.43 \\
2.72 \\
- \\
- \\
7.56 \\
-\end{array}$ & $\begin{array}{c}82.9 \\
82.9 \\
83.4 \\
- \\
- \\
83.0 \\
-\end{array}$ \\
\hline LANL & $\begin{array}{l}\text { Development } \\
\text { Scrap }\end{array}$ & $\begin{array}{l}4.42 \\
2.13\end{array}$ & $\begin{array}{l}3.66 \\
1.68\end{array}$ & $\begin{array}{l}82.84 \\
78.81\end{array}$ & 0.76 & $\begin{array}{l}4.38 \\
-\end{array}$ & $\begin{array}{c}3.62 \\
-\end{array}$ & $\begin{array}{l}82.7 \\
-\end{array}$ & $\begin{array}{l}4.36 \\
-\end{array}$ & $\begin{array}{c}3.60 \\
-\end{array}$ & ${ }^{82.6}$ \\
\hline Mound & $\begin{array}{l}\text { Q-1 } \\
\text { GPHS-Mods } \\
\text { Fueled Clads } \\
\text { MHW }\end{array}$ & $\begin{array}{l}8.90 \\
0.90 \\
2.38 \\
7.93\end{array}$ & $\begin{array}{l}7.33 \\
0.74 \\
1.96 \\
6.58\end{array}$ & $\begin{array}{l}82.36 \\
82.39 \\
82.43 \\
82.96\end{array}$ & $\begin{array}{l}1.57 \\
- \\
i .35\end{array}$ & $\begin{array}{c}8.83 \\
- \\
- \\
7.87\end{array}$ & $\begin{array}{c}7.26 \\
- \\
6.52\end{array}$ & $\begin{array}{l}82.2 \\
- \\
82.8\end{array}$ & $\begin{array}{l}8.77 \\
- \\
- \\
7.81\end{array}$ & $\begin{array}{l}7.20 \\
- \\
- \\
6.46\end{array}$ & $\begin{array}{c}82.1 \\
- \\
82.7\end{array}$ \\
\hline \multicolumn{2}{|c|}{ TOTAL (Italics Only) } & 53.06 & 44.05 & 83.02 & 9.01 & 52.63 & 43.62 & $82.9($ Ave) & 52.27 & 43.26 & 82.8 \\
\hline
\end{tabular}

(1) The program requires $47 \mathrm{~kg}$ of $\mathrm{Pu}$ for the flight units (assuming $90 \%$ yield each for chemical separation and pelletization thru accepted encapsulation).

(2) Based on a letter from A.P. Gouge to J.E. Dickenson dated 30 Aug 90. Care should be used in the application of these data since minor arithmetic inconsistencies appear to exist in this reference.

(3) $\mathrm{Pu}^{2 \mathrm{XX}}$ equals total $\mathrm{Pu}$ minus $\mathrm{Pu}^{238}$. 
Cassini spacecraft (S/C). Similarly, 3.0 years will pass between powder chemical separation and the launch of the CRAF S/C. Knowing the isotopic enrichment at time of encapsulation (BOL) we may calculate the approximate module BOL power using the relation shown in Equation 2.

Module Power, Watts $(t)=\left[\left[\frac{4 \text { fueled clads }}{\text { module }}\right]\left[\frac{150 \mathrm{gm} \mathrm{PuO}}{\text { fueled clad }}\right]\left[\frac{0.879 \mathrm{gm} \mathrm{Pu}}{\mathrm{gm} \mathrm{PuO}_{2}}\right]\left[\frac{0.5656 \text { watts }}{\mathrm{gm} \mathrm{Pu}^{238}}\right]\left[\frac{\% \text { enrichment }}{100}\right]\right]$

Exercising Equation 2 we see that for enrichments of 82.9 and 82.8 percent and, assuming that only a short time will pass between powder separation and encapsulation, we predict BOL powers of 247.3 watt $(t) /$ module and 247.0 watt $(t)$ / module for Cassini and CRAF respectively.

We may now recast Equation 1 in terms of power and present it as Equation 3.

$$
Q_{t}=Q_{0} e^{-\lambda t}
$$

where:

$$
\begin{aligned}
& Q_{t}=\text { Module power at time of interest, watt (t) } \\
& Q_{0}=\text { Module initial (BOM) power, watt }(t) \\
& e=2.7183 \\
& \lambda=\ln 2 / \text { isotopic half life, years }{ }^{-1} \\
& t=\text { time of interest, years }
\end{aligned}
$$

Given the GPHS module BOL powers shown above for Cassini and CRAF, and their respective decay times of 3.75 and 3.0 years to launch, we see that the Cassini and CRAF module BOM powers are approximately 240.1 and 241.2 watts (t) respectively.

Absent new fuel, we see that the issues previously presented in the problem statement are still present even if we select only the highest enrichment fuel available in the existing inventory. 


\section{Cassini Power Availability}

Performance estimates were prepared for a three-RTG Cassini configuration. This configuration uses the new F-6 RTG, the newly fueled F-2 RTG which makes use of the slightly degraded E-2 converter, and the aged F-5 RTG. For the purpose of this exercise, the F-2 and F-6 RTGs are assumed to be mounted in the C/C baseline $35^{\circ}$ separation positions and the F-5 RTG is assumed to be mounted approximately $180^{\circ}$ from the average F2 / F6 axis. The results of these performance estimates are presented in Figure 5 assuming that the RTGs are loaded with GPHS modules having three arbitrarily assumed thermal powers at launch (BOM). A histogram showing JPL desired power as a function of mission elapsed time (MET) is also included in this Figure.

Clearly, the proposed three RTG Cassini configuration provides adequate power margin $(+175$ watt (e) at Saturn encounter and +130 watt (e) at EOM when using 240 watt (t) modules) without any modifications to existing GPHS RTG hardware or complex gas management approaches. In fact, the power margin is so great that much lower enrichment fuel could be used. From a power availability point of view, the proposed three RTG Cassini

approach is eminently satisfactory. How much lower $\mathrm{Pu}^{238}$ enrichment might be used must await a more refined blending study and evaluation of the long term effects of the slight degradation which was introduced in E-2 testing.

\section{CRAF Power Availability}

Performance estimates were prepared for a two RTG CRAF configuration. This configuration uses the two new RTGs F-7 and F-8. These RTGs are assumed to be mounted in the $\mathrm{C} / \mathrm{C}$ baseline $35^{\circ}$ separation position. The results of these performance estimates are presented in Figure 6 for RTGs loaded with GPHS modules having three assumed thermal powers at launch (BOM). A histogram showing JPL desired power as a function of MET is also included in this Figure.

CRAF has a much lower predicted power margin than does Cassini. If new fuel comes into the program by Aug 92 , it is possible that a 245 watt $(t)$ BOM module could be available. Such a development would produce an adequate power margin throughout the Comet science 
Figure 5 Cassini Mission Power Supply and Demand as a Function of Time

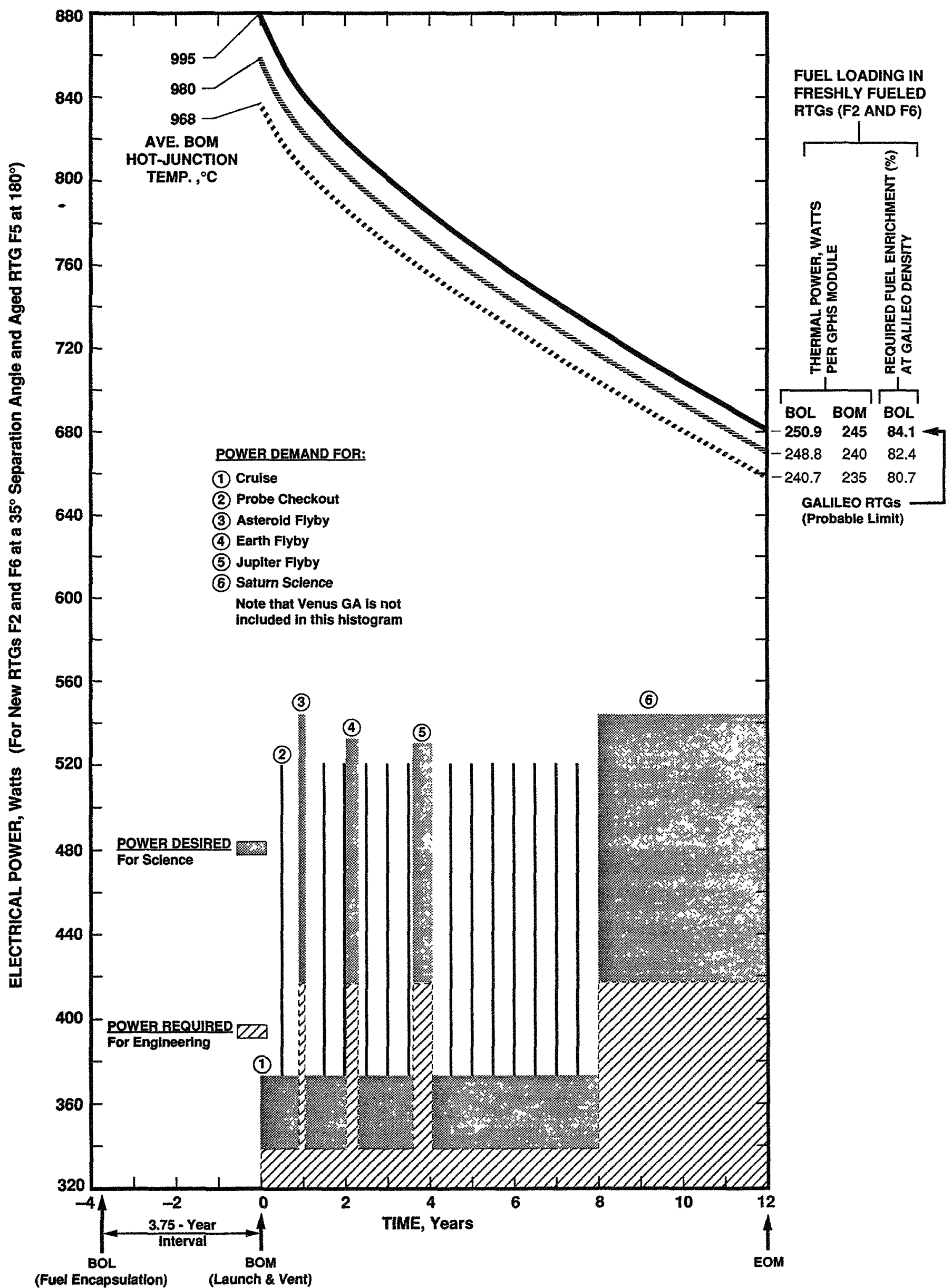


Figure 6 CRAF Mission Power Supply and Demand as a Function of Time

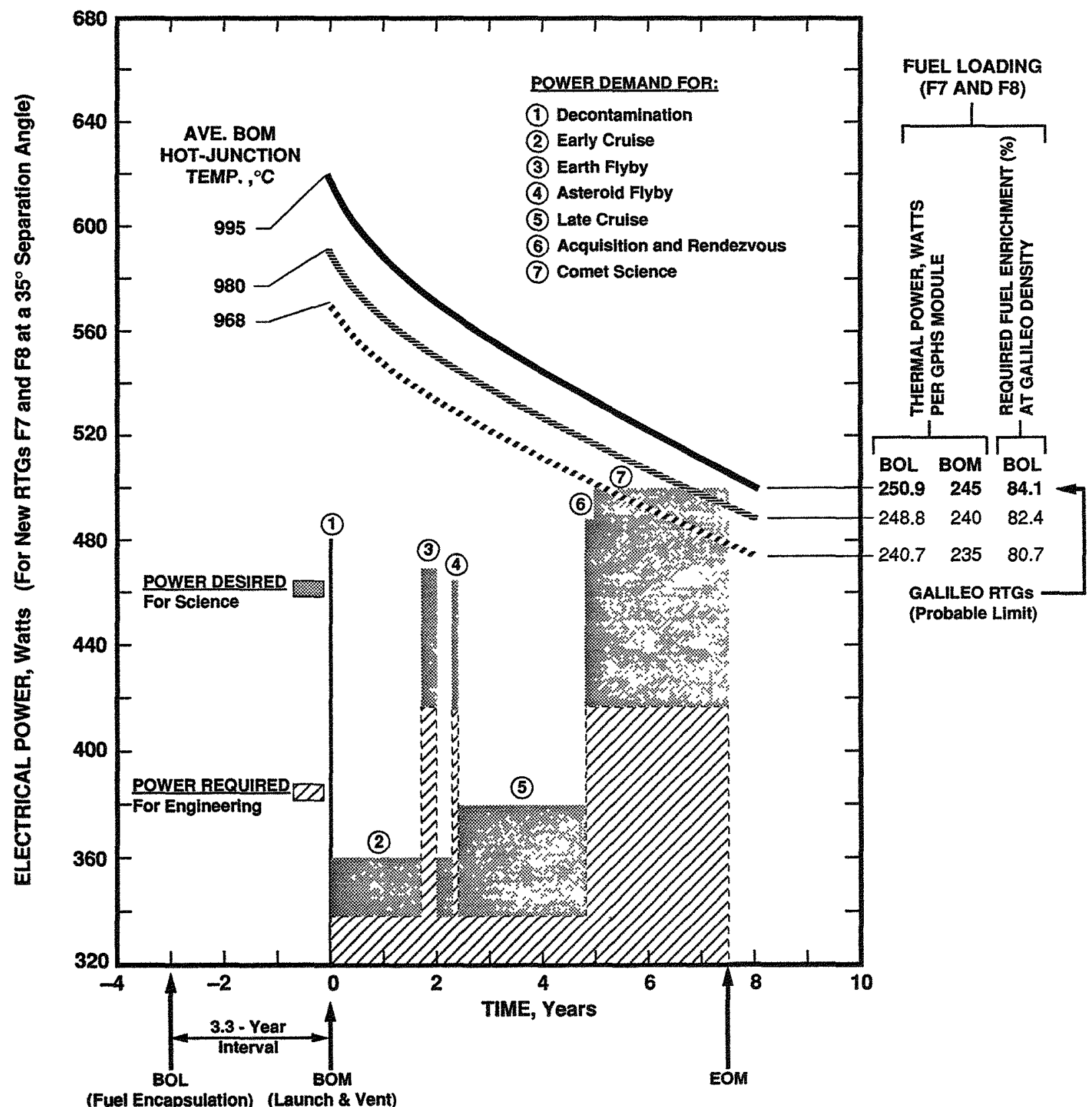


timeframe. If new fuel is not available, using the referenced 240 watt $(t)$ module yields, a +19 watt (e) margin at the beginning of Comet science and a -4 watt (e) margin at EOM. A 235 watt BOM module yields a +3 watt (e) margin at the beginning of Comet science and a - 18 watt (e) margin at EOM. Given that 240 watt (e) BOM modules are all we may have, some loss of Comet science occurs using the proposed approach. However, this approach provides a considerable improvement over the current baseline approach (see Table 2).

\section{E. Contingency Program-Plans}

Two contingency plans were developed for the $\mathrm{C} / \mathrm{C}$ program:

1. F-8 Contingency Program-Plan

2. F-9 Contingency Program-Plan

The F-8 contingency program-plan uses three RTGs in the Cassini mission. This configuration makes up the power deficiency of the current two-RTG Cassini-mission configuration and provides an additional 50 watts to eliminate the battery depth of discharge problem. The F-8 contingency plan uses two RTGs for CRAF and obtains additional power by using the new fuel which comes into the program in March 93. Additional power could also be obtained from gas management strategies and converter fin length increases. This additional power can be used to reduce the CRAF battery depth of discharge, but under this scenario, CRAF must still fly batteries.

The F-9 contingency program-plan uses three RTGs for both missions. This is accomplished by building a fifth heat source, fueling E-9, and building a fifth converter (E-10) as a spare. The F-9 contingency program-plan requires a delay of the launch of the CRAF mission until 26 Aug 96.

\section{F-8 Contingency Program-Plan}

An 800 activity data base was developed for the proposed contingency program-plan. A summary schedule of major activities and milestones is presented in Figure 7. This figure 


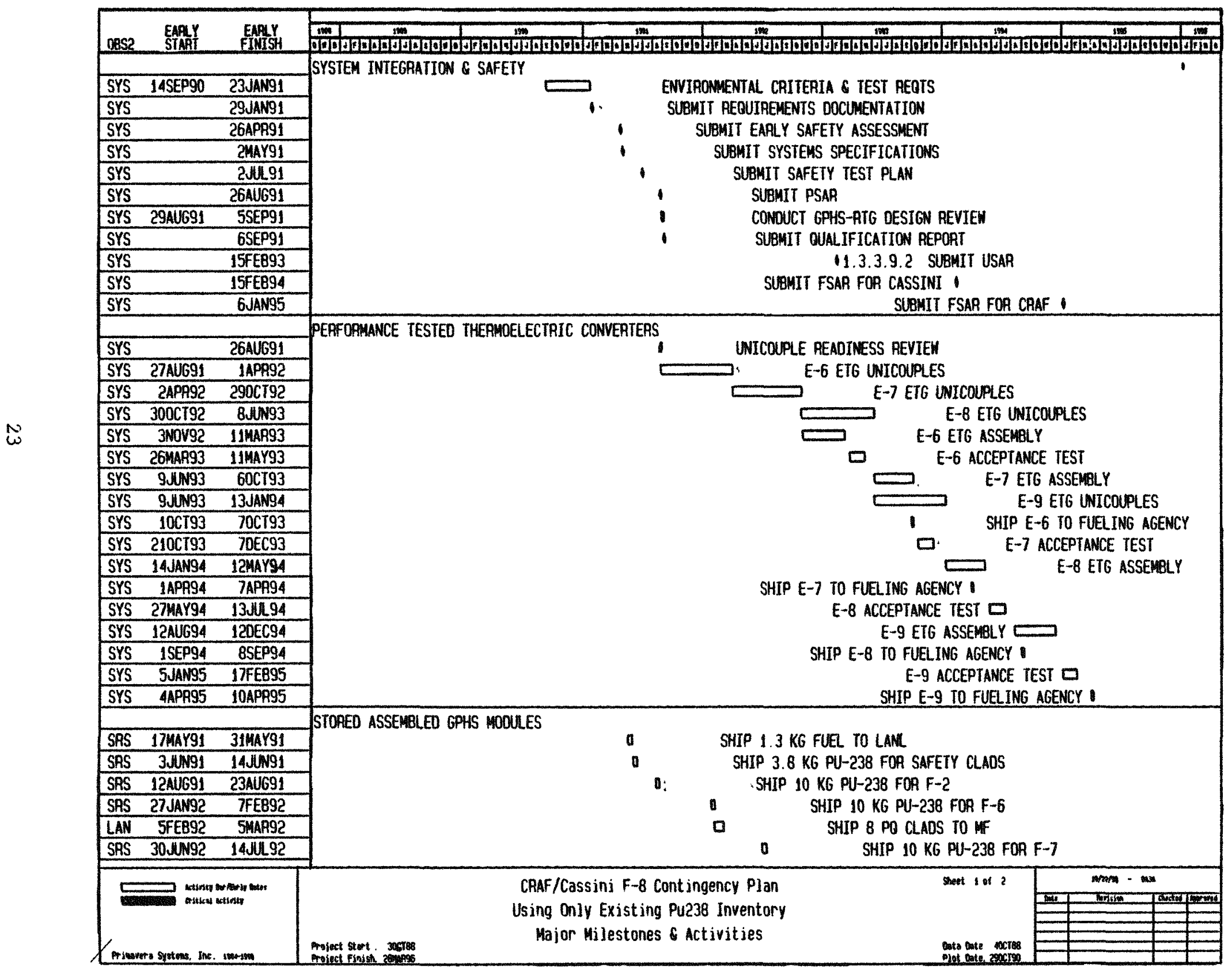

Figure 7 (Page 1 of 2) 


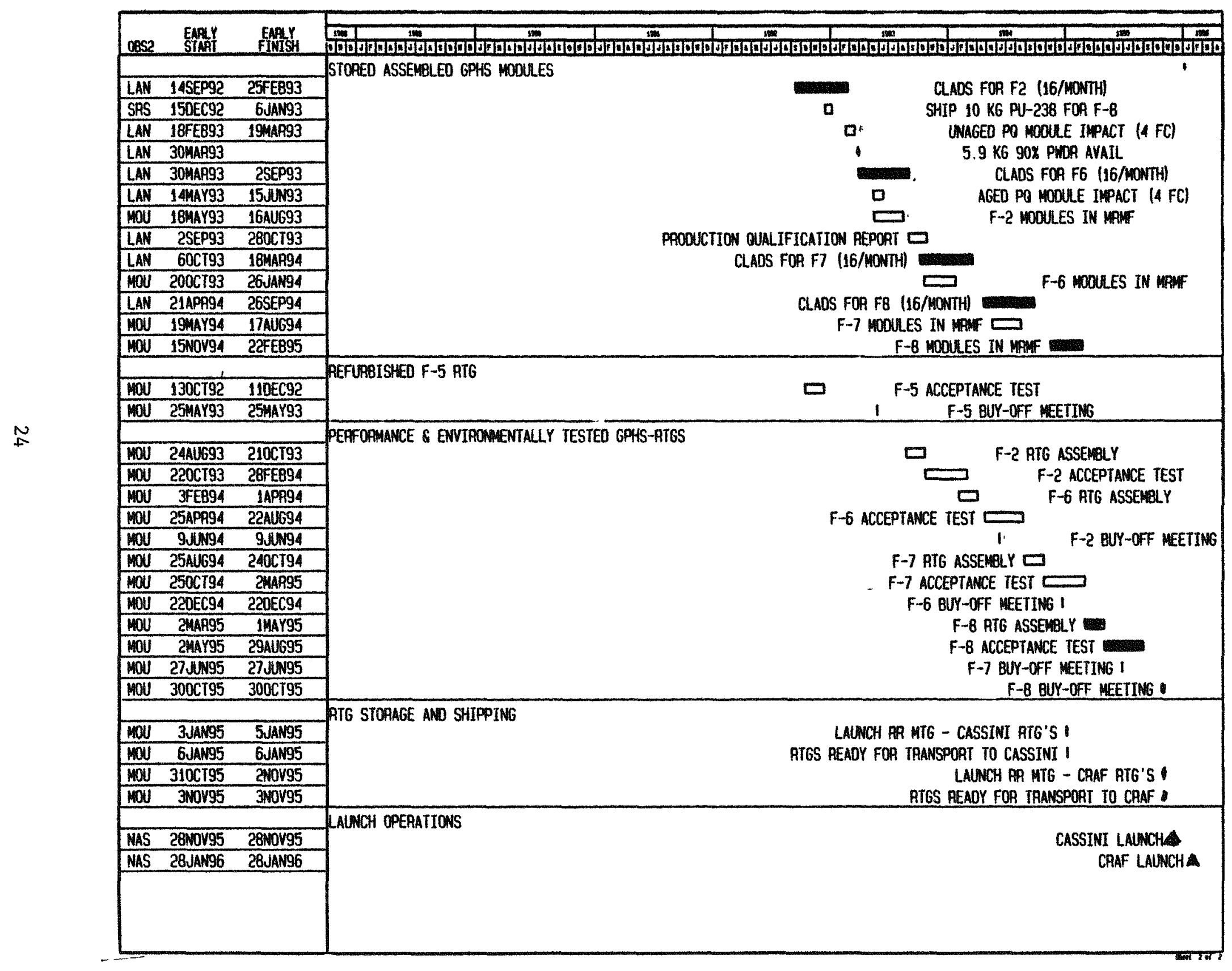


shows a contingency-plan schedule which is analogous to the current baseline plan previously presented in Figure 1.

Under the proposed contingency plan, acceptance testing of the Cassini RTGs will be completed 15 months before launch. The E-7 converter will be available in time to support any F-6 acceptance test problems. It is assumed that F-2 (which currently exists) will be brought forward and fueled with the existing F-5 heat source if F-5 gets into trouble in the preload adjustment maneuver. If E-7 must be brought forward for Cassini, E-9 must be fueled for CRAF and there will be no CRAF spare.

Under the proposed contingency plan, the CRAF RTGs will complete acceptance testing in August 1995. This date could be improved if changes in the campaigning strategy which is currently in use at Mound were made. The FWPF billet manufacturer would actually prefer a shorter production run. This approach would require some NASA funding to be moved into FY-92 from FY -93.

Total program budget and budget split by funding agency are presented in Figures 8 thru 10. The primary budget impact caused by the contingency plan occurs because of the need to assemble and test E-9 in time to allow E-7 to be a viable spare for F-6. The net effect of this requirement is to raise the contingency plan budget by approximately four million dollars above the current (four heat source) $\mathrm{C} / \mathrm{C}$ baseline budget. This increase would occur in FY-94. Although the contingency plan proposed by the CRAF program has positive float, it would appear prudent to attempt to advance the date at which F-8 and E-9 components are available. No attempt was made to compress the F-8 schedule in the baseline plan because, at that time, there was no need to do so. E-9 components are not assembled under the baseline plan.

No attempt to accomplish F-8 schedule compression was made for this exercise since this would require detailed interactions with Mound and LANL personnel, and it was feit that this would be inappropriate given the other demands which currently exist on their time. One can always say that F-8 schedule compression can be accomplished by increasing funding (more staff or overtime and two shift operations at Mound and at the converter manufacturer). 
There was no Page 26 in original document. 
There was no Page 27 in original document. 
There was no Page 28 in original document. 
The only identified problem area unique to the proposed contingency plan appears to be FWPF billet availability. This is already a critical item for which Mound needs purchase authority.

\section{F-9 Contingency Plan}

A new data base similar to the F-8 data base was created for the F-9 contingency plan. A summary schedule of major activities and milestones is presented in Figure 11. This figure is analogous to the baseline and F-8 contingency-plan schedules shown in Figure 1 and Figure 7 respectively. The F-9 contingency plan assumes the same aggressiveness as the F-8 plan. It is seen that under this plan, the third RTG for the CRAF mission would not be available until 26 Aug 96. As a result, the CRAF launch could not occur until 26 Aug 96. Given this delay, it might be more reasonable to launch the CRAF using the F-2, F-5 and F-6 RTGs at the 28 Jan 96 opportunity and launch Cassini on or after 26 Aug 96.

Total budget and budget split by funding agency are presented in Figures 12 through 14 . The net effect of fueling F-9 and fabricating E-10 is to raise the F-9 contingency plan budget million dollars above the baseline (four heat source) budget. 


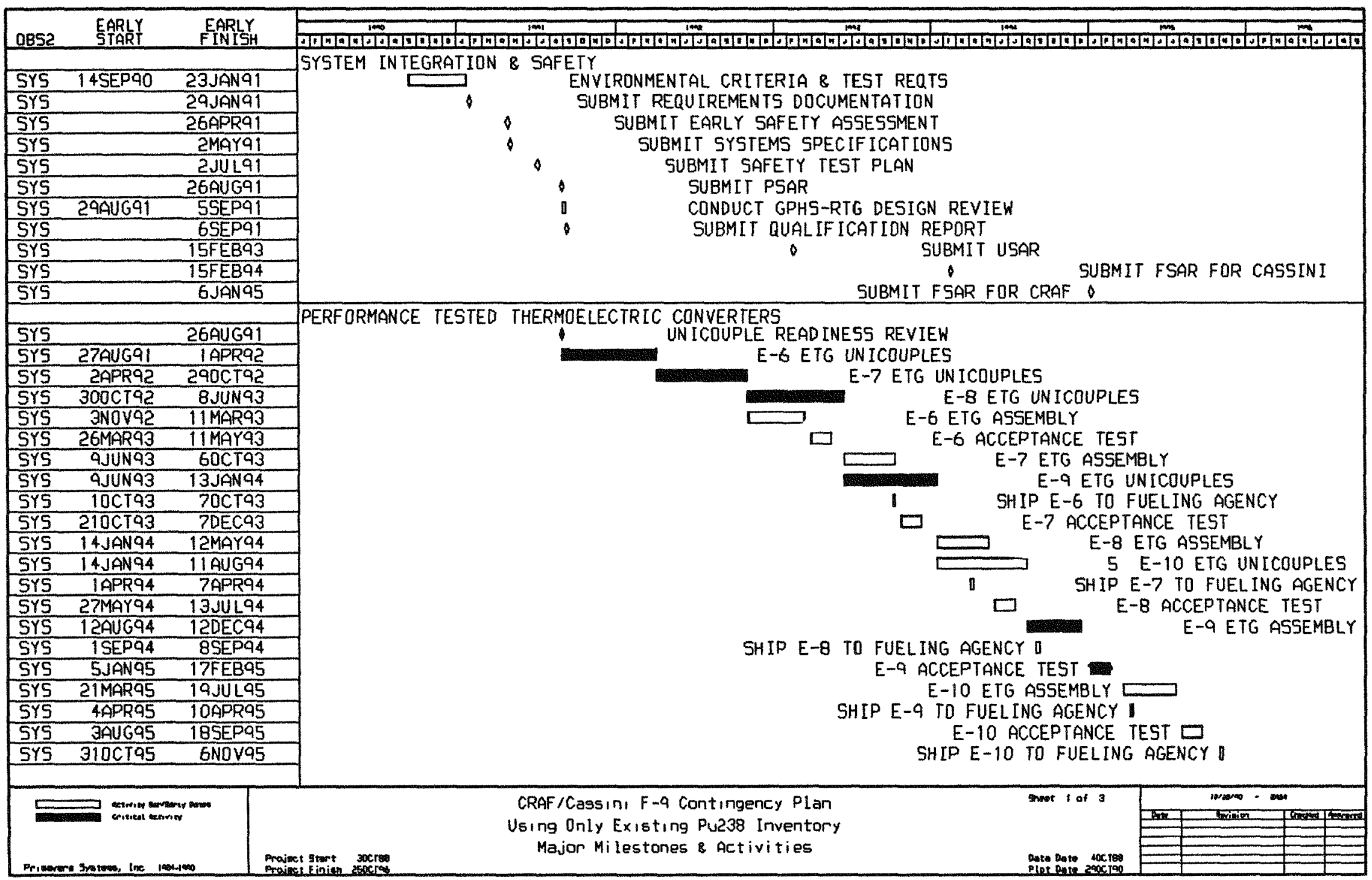

Figure 11 (Page 1 of 3 ) 


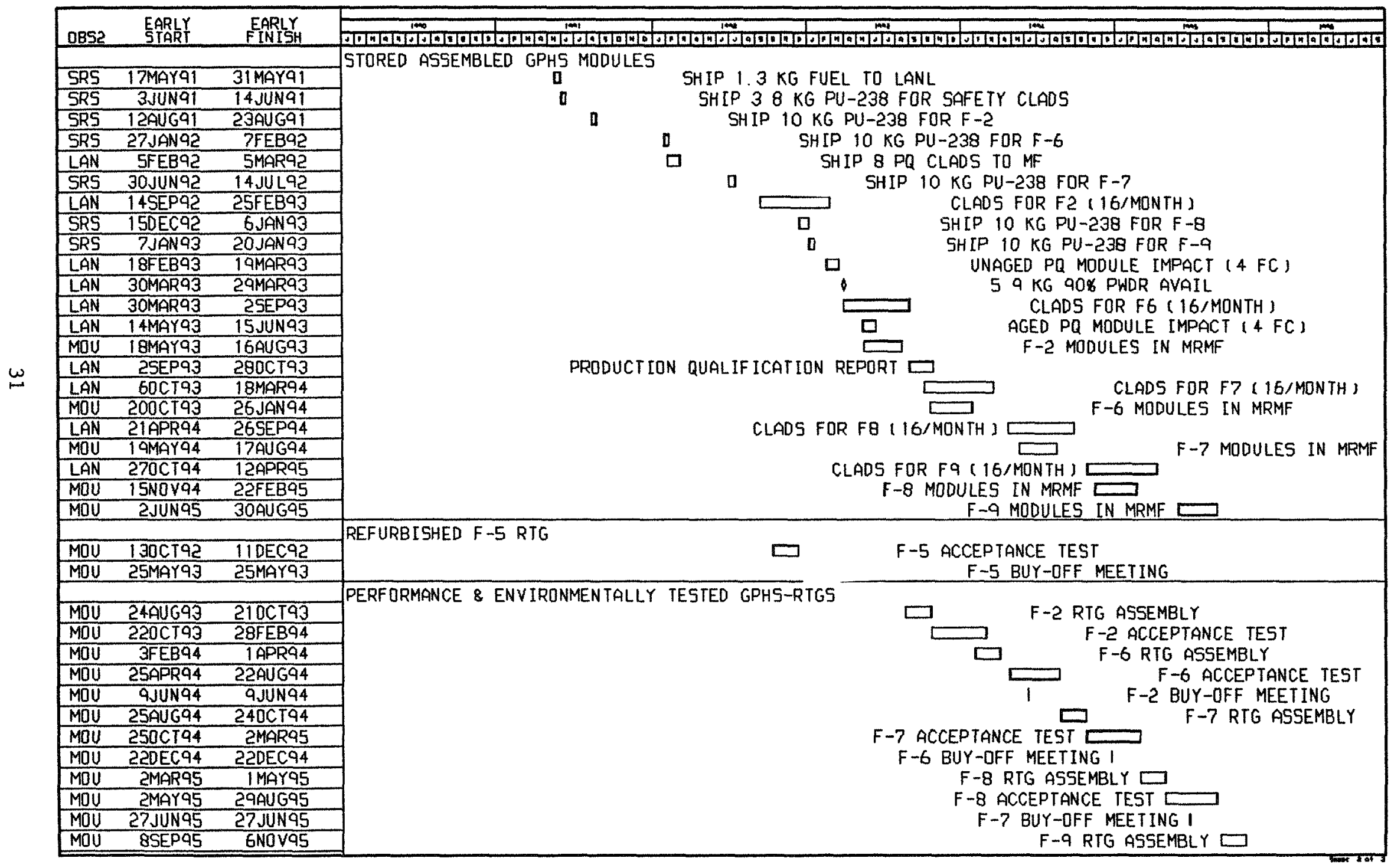


-

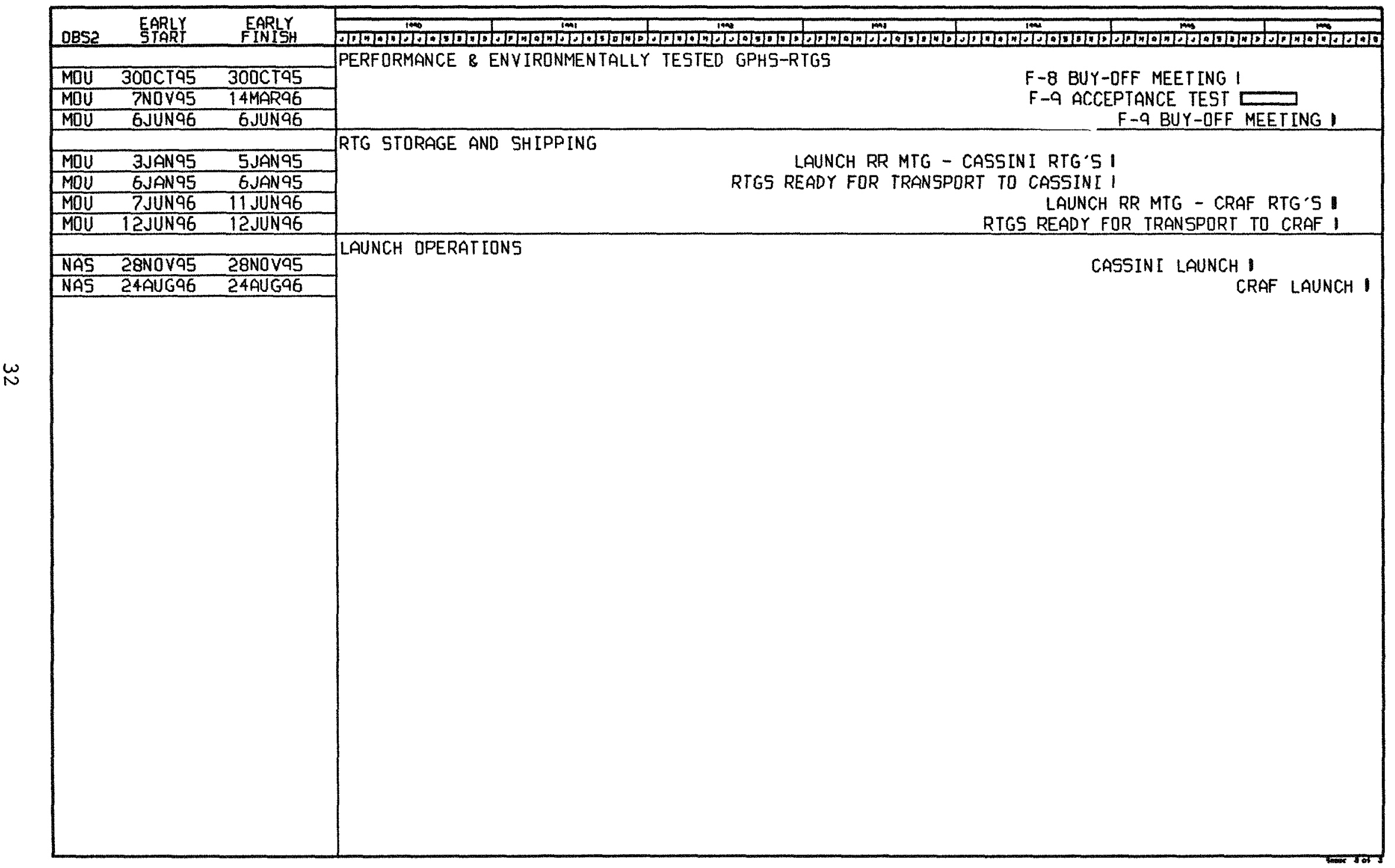

Figure 11 (Page 3 of 3 ) 
There was no Page 33 in original document. 
There was no Page 34 in original document. 
There was no Page 35 in original document. 


\section{CONCLUSIONS}

1. If newly made $\mathrm{Pu}^{238}$ does not reach the pelletizer by April 1992, CRAF will miss either its power supply goal or its launch date under the current $\mathrm{C} / \mathrm{C}$ program plan $\left(\mathrm{Np}^{237}\right.$ -irradiation must start by June 1991 if chemically separated powder is to be available for shipment by April 1992. The state of $\mathrm{Np}^{237}$ target fabrication was not determined).

2. The Cassini power supply goals cannot be met using any practical $\mathrm{Pu}^{238}$ enrichment and the assumptions of the current $\mathrm{C} / \mathrm{C}$ program plan.

3. If new fuel is not available, less than half of the Cassini Saturn- science power demand can be supplied.

4. The current $\mathrm{C} / \mathrm{C}$ program plan should be modified so as to either reduce power demand or increase power supply for both the CRAF and Cassini missions.

5. A scenario (F-8 contingency program-plan) has been identified under which existing CRAF and Cassini power supply goals could be met if the launch order were inverted. If Cassini were launched 28 Nov 95 and flown on a VEJGA trajectory with three RTGs (F2, F-5, and F-6), substantial additional power would be available for Saturn science. Only $\mathrm{Pu}^{238}$ from the existing U.S. inventories would be required under this scenario.

6. CRAF Comet-science power demands could be met under the proposed scenario using a 28 Jan 96 launch opportunity and fuel from existing U.S. inventories.

7. The proposed F-8 contingency plan increases Cassini float but decreases CRAF float. If this scenario were adopted, prudence would require that an aggressive attempt be made to shorten the E-8, E-9, and F-8 delivery schedules.

8. An alternate contingency program-plan (F-9) was also developed. Under this plan, both CRAF and Cassini would carry three RTGs. The launch of the second mission would be delayed until Sept 96 if this plan were adopted. 
9. Under the F-9 contingency program-plan the budget would be increased million dollars above the baseline (four heat source) budget.

10. Either of the proposed scenarios is feasible, but they are sufficiently aggressive that proactive management would be required both at DOE and JPL. The higher cost of the RTG budget and the program costs involved in stretching out the schedule for a Sept 96 launch would argue for use of the F-8 scenario.

11. On balance, it is concluded that, for the three cases studied, the F-8 contingency plan (Cassini launched at the 28 Nov 95 opportunity and CRAF launched at the 28 Jan 96 opportunity) will produce the greatest science return on investment. 